\title{
Seroprevalence of Theileria equi and Babesia caballi in horses in Spain
}

\author{
Maria Guadalupe Montes Cortés ${ }^{1}$, José Luis Fernández-García ${ }^{2, *}$, \\ and Miguel Ángel Habela Martínez-Estéllez ${ }^{1}$ \\ 1 Parasitology and Parasitic Diseases, Animal Health Department, Veterinary Faculty, University of Extremadura, 10071 Cáceres, Spain \\ 2 Genetics and Animal Breeding, Veterinary Faculty, University of Extremadura, 10071 Cáceres, Spain
}

Received 17 January 2017, Accepted 17 April 2017, Published online 12 May 2017

\begin{abstract}
Equine piroplasmoses are enzootic parasitic diseases distributed worldwide with high incidence in tropical and subtropical regions. In Spain, there is insufficient epidemiological data about equine piroplasmoses. The main aim of the present study was therefore to estimate the prevalence of Theileria equi and Babesia caballi in five regions and obtain information about the risk factors. This study was conducted in the central and south-western regions of Spain, using indirect fluorescence antibody testing (IFAT) in 3,100 sera samples from apparently healthy horses of different ages, breeds, coat colours, genders and geographical locations. The overall seroprevalence was $52 \%$, consisting of $44 \%$ seropositive for $T$. equi and $21 \%$ for $B$. caballi. There was a significant association between age $(p<0.0001)$, breed $(p<0.004)$, geographical location $(p<0.0001)$ and the seroprevalence, but neither the coat colour nor the gender was significantly associated with prevalence. In addition, it was proved that most of the geographic areas showed a moderate to high prevalence. The statistical $\kappa$ value was used to compare the results obtained by the IFAT and the competitive enzyme-linked immunosorbent assay (cELISA) utilised to test some samples $(n=108)$ and showed a higher concordance for $T$. equi $(\kappa=0.68)$ than for B. caballi $(\kappa=0.22)$. Consequently, this revealed the importance of developing an appropriate technique to detect each haemoparasite.
\end{abstract}

Key words: Equine piroplasmoses, Spain, Seroprevalence, IFAT, cELISA.

Résumé - Séroprévalence de Theileria equi et Babesia caballi chez les chevaux en Espagne. Les piroplasmoses équines sont des parasitoses enzootiques cosmopolites qui existent surtout dans les régions tropicales et subtropicales. En Espagne, peu de données épidémiologiques sont disponibles sur les piroplasmoses équines. Ainsi, le principal objectif de la présente étude a été d'estimer la séroprévalence de l'infection par Theileria equi et Babesia caballi dans cinq régions et obtenir des informations sur les facteurs de risque. Cette étude a été menée dans les régions du centre et du sud-ouest de l'Espagne en utilisant le test d'immunofluorescence indirecte (IFI) sur un échantillon de 3100 sérums de chevaux apparemment sains de différents âges, races, robes, sexe et origines géographiques. La séroprévalence globale était de $52 \%$, y compris $44 \%$ séropositifs pour T. equi et $21 \%$ pour B. caballi. Il y avait une association significative entre l'âge $(p<0.0001)$, la race $(p<0.004)$, la localisation géographique $(p<0.0001)$ et la séroprévalence. Cependant, ni la couleur du pelage ni le sexe n'avaient de corrélation significative avec la séroprévalence. En outre, la plupart des régions étaient dans un état de prévalence modérée à élevée. Le coefficient de concordance $\kappa$ a été utilisé pour comparer les résultats obtenus par IFI et cELISA pour tester 108 échantillons, et a montré une concordance plus élevée pour $T$. equi $(\kappa=0.68)$ que pour B. caballi $(\kappa=0.22)$. Cela démontre l'importance de développer une technique appropriée pour détecter chaque hémoparasite.

\section{Introduction}

Equine piroplasmoses (EPs) are important and widespread tick-borne diseases in horses. This parasitic disease affects all equid species including horses, donkeys, mules and zebras. Two species of parasites, Babesia caballi (Nuttall and

\footnotetext{
*Corresponding author: pepelufe@unex.es
}

Strickland 1910) and Theileria equi (formerly Babesia equi, Laveran 1901), cause this infection. These protozoa parasitise erythrocytes and they can co-infect animals [18, 65, 83]. The disease is characterised by a variety of symptoms such as fever, anaemia, jaundice, haematuria and lymphadenopathy [32]. The initial acute phase can cause death, but the survivor animals become carriers and reservoirs of infection for vector ticks [28]. Therefore, large economic losses are generated due 
to the treatments, the decrease in performance of the animals or the negative impact on international trade $[31,56]$.

In Spain, EPs are enzootic diseases [13, 31] as they have been diagnosed in autochthonous horses for decades [21, 22, 41-43] but there is insufficient epidemiological information about this disease and its vectors in Spain.

Several diagnostic methods are used to detect the infection, such as microscopic examination of stained blood smears, which is useful in the acute phase of infection onset, though serological techniques are better in order to identify chronic carriers. These techniques include the complement fixation test (CFT), the indirect fluorescent antibody test (IFAT), and the competitive enzyme-linked immunosorbent assay (cELISA), which utilises the EMA-1 protein and a specific monoclonal antibody (MAb) to detect T. equi, and the recombinant $R A P-1$ protein and an MAb reactive with a peptide epitope of a 60 KDa B. caballi antigen to diagnose the other parasite. The last two tests are recommended by the World Organisation for Animal Health (OIE) for the serodiagnosis of EP [73]. The diagnosis of these haemoprotozoan infections can be carried out using molecular assays such as conventional single PCR [13], multiplex PCR [7, 96], nested PCR [72, 78, 95] or real-time PCR [54]. Thus, the combination of two or more of these methods is currently recommended to diagnose the EP [102].

The main goal of this survey was to estimate the seroprevalence and geographic distribution of EP in central and southwest Spain. In fact, it is the largest study that has been conducted in Spain. It is intended to identify areas in which to implement more effective control measures against both the pathogens and their vectors. In addition, we analysed 108 randomly selected sera samples to compare concordance of the two serological methods most often used in the diagnosis of this parasitic infection that affects equids in Spain: the indirect fluorescence antibody test (IFAT) vs. an immunoenzymatic assay (cELISA). This study helped to further understand the situation of the Purebred Spanish Horse with regard to these infections in this emblematic and autochthonous breed.

\section{Materials and methods}

\section{Sampled animals and area of study}

This study was carried out between February and September 2014 in various regions of Spain: Andalusia, Castilla-La Mancha, Castilla-León, Extremadura and Madrid (Fig. 1). Blood samples were collected from horses' jugular veins into sterile vacuum tubes with and without anticoagulant. Plasma and serum samples were obtained by centrifugation at $4^{\circ} \mathrm{C}$ at $2500 \mathrm{rpm}$ for $10 \mathrm{~min}$ and were stored at $-20^{\circ} \mathrm{C}$ until testing. The plasma and sera were used for the IFAT and the cELISA, respectively.

This study included 3100 animals (1309 females and 1791 males) with no clinical signs of piroplasmoses between 9 months and 30 years of age (mean age: 7.5 years). Different breeds were tested including the Spanish Pure Breed horse, Anglo-Arabian, Arabian horse, Balearic horse, Hanoverian horse, Lusitano, Thoroughbred, Selle Français and crossbred horses. Information on aptitude was annotated; thus, most of the animals were breeding horses though there were saddle horses (recreation or sports). Data were studied according to recorded information sent by owners and/or veterinarians: gender, breed, age, geographical origin and coat colour.

Win Episcope 2.0 was used [99] to estimate the minimal sample size needed to guarantee the validity of this study. According to the equine census data obtained in 2013 from MAGRAMA ("Ministerio de Agricultura, Alimentación y Medio Ambiente", Spain) [61] in each region studied (Table S1), at least 381 animals from each area were sufficient in order to detect a $50 \%$ prevalence of subclinical EP infection with a certainty of $95 \%$ [89]. However, in the region of Madrid, the sample size was smaller than necessary $(n=312)$ (Fig. 1, Table S1).

\section{Indirect fluorescence antibody test (IFAT) and immunoenzymatic assay (cELISA)}

The IFAT was used for the detection of antibodies against T. equi and B. caballi. The antigen was obtained from naturally infected horses with a parasitaemia higher than $3 \%$. Both protocols to prepare the T. equi and the B. caballi antigen and the assay were conducted as described by Camacho et al. [21]. The slides were examined under the fluorescence microscope $\left(\right.$ Leica DMLS $\left.^{\circledR}\right)$ at a magnification of $400(10 \times 40)$. Positive and negative sera were included in each run as controls.

The cELISA test was carried out with commercially available test kits (VMRD, Inc. Pullman, WA, USA) to detect antibodies against $T$. equi and $B$. caballi. These tests were conducted following the manufacturer's instructions. The plates were read on a plate reader (Multiskan Ascent, Thermo Electron Corporation $\left.{ }^{(}\right)$at an optical density of $620 \mathrm{~nm}$. Samples associated with percent inhibition (PI) values $<40 \%$ were considered negative, while if the PI value was $\geq 40 \%$, sera were considered positive.

The IFAT and the cELISA techniques are the most useful methods to diagnose equine piroplasmoses. For this reason, a comparison between the techniques was needed since it had not been done previously in Spain. Thus, from the 3100 serum samples tested by IFAT, 108 samples were randomly selected and tested by cELISA.

\section{Statistical analysis}

The seroprevalences of T. equi, B. caballi and co-infection relative to certain characteristics (age, breed, coat colour, gender and geographical location) were determined at the $95 \%$ confidence interval $(\mathrm{CI})$. These epidemiological data were compared with the IFAT results using a logistic regressionbinary (LR-binary). Animals were considered as units of analysis for determining the significance of association. Data analyses were performed using Statistical Package for Social Sciences (SPSS) 11.0 software for Windows. The odds ratios were calculated at a $95 \%$ confidence interval $(95 \% \mathrm{CI})$. Tests with a $p$-value $\leq 0.05$ were considered statistically significant.

Due to the semi-quantitative characteristic of age as a variable, it was evaluated by both (i) exploring the difference in means between categories in the IFAT variable, and (ii) using 


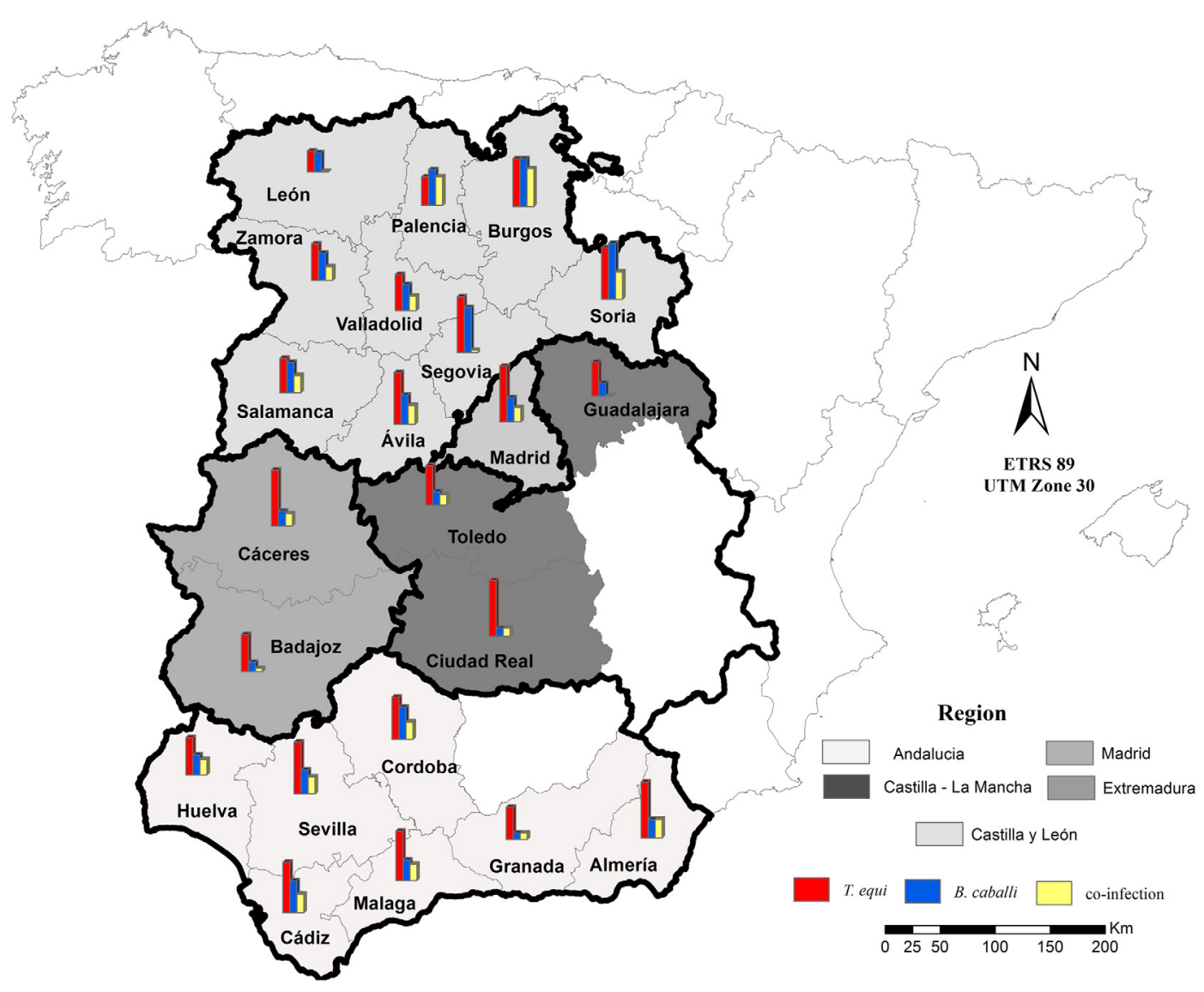

Figure 1. Map of equine piroplasmosis prevalence by region in Spain. The histogram within each province represents the positive horses using percentages.

it as an ordinal variable, then using the OR calculated as the average value of each risk factor compared to the previous in descending order. The statistical significance of seroprevalence between pairs of regions (Castilla-La Mancha, Andalusia, Castilla-León, Extremadura and Madrid) was calculated using a non-parametric test with the Monte Carlo Method. In order to determine the concordance between the two serological techniques (the IFAT and the cELISA), Cohen's $\kappa$ test was used [24]. The $\kappa$ values $<0$ indicate no agreement and values between 0 and 0.20 indicate slight agreement, $0.21-0.4$ fair agreement, $0.41-0.60$ moderate, $0.61-0.80$ substantial and 0.81-1 almost perfect agreement.

\section{Results}

\section{Seroepidemiological study}

The serological examination of 3100 horses by IFAT showed that the overall seroprevalence of the equine piroplasmoses in southwest Spain was 52.45\% $(S E=0.009)$. Of the 3100 tested samples, 1381 sera $(44.55 \% ; S E=0.009)$ were positive for T. equi, 643 samples $(20.74 \% ; S E=0.007)$ were positive for $B$. caballi and 398 horses $(12.84 \% ; S E=0.006)$ had antibodies against both parasites.

The seroprevalence in horses from Castilla-La Mancha was the highest (67.54\%) (significance calculated by the Monte
Carlo method $[95 \% \mathrm{CI}] ; p<0.001)$. The prevalence results in horses from Andalusia, Castilla-León and Extremadura (50.94\%; 53.62\% and 51.5\%, respectively) were not statistically significant (significance calculated by the Monte Carlo method $[95 \% \mathrm{CI}] n s$ ). The lowest seroprevalence was observed in Madrid (38.14\%) (significance calculated by the Monte Carlo method [CI 95\%]; $p<0.001$ ) (Table 1). The mean age by region was as follows: $6.24 \quad(S E=0.183), 7.15$ $(S E=0.250), 10.25(S E=0.320), 6.43(S E=0.161)$ and $8.26(S E=0.384)$ years for Andalusia, Castilla-La Mancha, Castilla-León, Extremadura and Madrid, respectively.

In this study, it has been shown that T. equi, B. caballi and mixed infection were detected across regions. Notably, the parasite detected most frequently was $T$. equi, ranging from 62.57 to $32.37 \%$ in Andalusia and Madrid, respectively (Table 1). However, B. caballi prevalence was half as high, ranging from 31.16 to $12.20 \%$ in Castilla-León and Extremadura, respectively (Table 1). The maximum of mixed infections was $16.38 \%$ in Castilla-León (Table 1). The regional seroprevalence for male and female horses is shown in Table 1 (see also Table S2 for province details).

Approximately half of the tested Spanish Pure Breed horses were seropositive $(50.89 \%)$ consisting of $41.69 \%$ horses T. equi seropositive and $16.32 \%$ seropositive for B. caballi. Meanwhile, $9.90 \%$ of the tested horses were positive for both parasites. 
Table 1. Prevalence of $T$. equi and B. caballi antibodies (by IFAT) in horses from different regions of Spain

\begin{tabular}{clllll}
\hline Region & Seroprevalence & \multicolumn{1}{c}{ T. equi $(\% \pm S E)$} & \multicolumn{1}{c}{ B. caballi $(\% \pm S E)$} & Co-infection $(\% \pm S E)$ & Total $(\% \pm S E)$ \\
\hline Andalusia & Males & $241 / 560(43.04 \pm 0.021)$ & $105 / 560(18.75 \pm 0.017)$ & $77 / 560(13.75 \pm 0.014)$ & $269(48.04 \pm 0.021)$ \\
& Females & $175 / 394(44.42 \pm 0.025)$ & $107 / 394(27.16 \pm 0.022)$ & $65 / 394(16.50 \pm 0.019)$ & $217(55.07 \pm 0.025)$ \\
& Overall & $416(43.61 \pm 0.016)$ & $212(22.22 \pm 0.013)$ & $142(14.88 \pm 0.011)$ & $486(50.94 \pm 0.016)$ \\
Castilla-La & Males & $125 / 207(60.39 \pm 0.034)$ & $42 / 207(20.29 \pm 0.028)$ & $34 / 207(16.43 \pm 0.026)$ & $133(64.25 \pm 0.033)$ \\
Mancha & Females & $114 / 175(65.14 \pm 0.036)$ & $37 / 175(21.14 \pm 0.031)$ & $26 / 175(14.86 \pm 0.027)$ & $125(71.43 \pm 0.034)$ \\
& Overall & $239(62.57 \pm 0.025)$ & $79(20.68 \pm 0.021)$ & $60(15.71 \pm 0.019)$ & $258(67.54 \pm 0.024)$ \\
Castilla-León & Males & $165 / 424(38.92 \pm 0.024)$ & $130 / 424(30.66 \pm 0.022)$ & $62 / 424(14.62 \pm 0.017)$ & $233(54.95 \pm 0.024)$ \\
& Females & $103 / 266(38.72 \pm 0.030)$ & $85 / 266(31.95 \pm 0.029)$ & $51 / 266(19.17 \pm 0.024)$ & $137(51.50 \pm 0.031)$ \\
& Overall & $268(38.84 \pm 0.019)$ & $215(31.16 \pm 0.018)$ & $113(16.38 \pm 0.014)$ & $370(53.62 \pm 0.019)$ \\
Extremadura & Males & $167 / 391(42.71 \pm 0.025)$ & $61 / 391(15.60 \pm 0.018)$ & $34 / 391(8.70 \pm 0.014)$ & $194(49.61 \pm 0.025)$ \\
& Females & $190 / 371(51.21 \pm 0.026)$ & $32 / 371(8.63 \pm 0.015)$ & $23 / 371(6.20 \pm 0.013)$ & $199(53.64 \pm 0.026)$ \\
& Overall & $357(46.85 \pm 0.018)$ & $93(12.20 \pm 0.012)$ & $57(7.48 \pm 0.010)$ & $393(51.67 \pm 0.018)$ \\
Madrid & Males & $68 / 209(32.54 \pm 0.032)$ & $24 / 209(11.48 \pm 0.022)$ & $15 / 209(7.18 \pm 0.018)$ & $77(36.84 \pm 0.033)$ \\
& Females & $33 / 103(32.04 \pm 0.046)$ & $20 / 103(19.42 \pm 0.039)$ & $11 / 103(10.68 \pm 0.031)$ & $42(40.78 \pm 0.049)$ \\
& Overall & $101(32.37 \pm 0.027)$ & $44(14.10 \pm 0.020)$ & $26(8.33 \pm 0.016)$ & $119(38.14 \pm 0.028)$ \\
\hline
\end{tabular}

$(S E=$ Standard Error)

Regarding the goodness of the LR-binary model $\left(\chi^{2}=372.93 ; \quad p<0.0001\right.$ and $B=0.098 \quad(S E=0.038)$; $p<0.006)$, age $(p<0.0001)$, breed $(p<0.004)$ and geographical location $(p<0.0001)$ were significant, explaining between 0.155 (Cox and Snell's $R^{2}$ ) and 0.207 (Nagelkerke's $R^{2}$ ) of the dependent variable (seroprevalence), with $62.4 \%$ of the cases correctly classified. This indicates that the model is acceptable. Other risk factors, the coat colour and the gender, were not significant and fall out of the model (Tables S3 and S4 for T. equi and B. caballi, respectively, for details). The difference between average age of the positive and the negative horses (6.92 [95\% CI: 6.61-7.22] subtracted from 8.19 [95\% CI: 7.86-8.53]) by the T. equi IFAT test was 1.27 years. On the basis of these results, non-overlap between the CIs of the average ages supported statistically significant differences in the age of seropositivity, based on the IFAT test. Moreover, the OR values between a specific age and the previous one were slightly similar but significantly increased from three to 11 years of age. This was accompanied by a change of significance regarding the percentages in seroprevalence, reaching a threshold of around $44-65 \%$ of positivity from eleven years of age. Regarding the breed, OR values are significantly different among non-native breeds such as Arabian horses, Thoroughbred, Selle Français and crossbreeds, which always showed OR values higher than those from the autochthonous breeds like Spanish Pure Breed horses for T. equi. Focusing on the geographical distribution, it was observed that there was a higher risk of $T$. equi infection in Extremadura and Castilla-León since the OR was significant.

A similar result was obtained for $B$. caballi, since neither coat colour nor gender was risk factor for this parasitic infection. The difference between the average age for seronegative and seropositive horses was 1.75 years $(7.14$ [95\% CI: 6.90-7.39], that is the mean age of seronegative horses, subtracted from 8.89 [95\% CI: 8.31-9.57], that is the mean age of seropositive through the IFAT test). This difference was slightly higher than that for $T$. equi. The infection risk increased until 12 years of age; from there, the seropositivity settled around $20-45 \%$ and there were no significant differences of seroprevalence above 12 years of age. However, the OR between a specific age group and the previous one for $B$. caballi was about three times higher than for $T$. equi, but turnover (more frequent negativity change to more frequent positivity) in favour of positivity from the nine-year threshold occurs only for T. equi (Table S3). There was a significant association between the breeds Arabian horses and Thoroughbred, and seropositivity for B. caballi. The seropositivity rate in Extremadura was significantly lower than in other regions.

\section{IFAT vs. cELISA results}

The concordance between the techniques was similar. Of the 108 tested sera samples, both diagnostic methods showed concordant results for T. equi in 91 sera $(84.26 \%)$, meanwhile for $B$. caballi the same results were observed in 89 samples $(82.41 \%)$. Focusing on the anti-T. equi antibodies, 7 sera were positive by IFAT but were found negative by the cELISA, and 10 serum samples were negative by IFAT but positive by cELISA. Analysing the $B$. caballi results, it was found that 16 horses had antibodies for that parasite by IFAT but did not show reactivity in the cELISA, and three animals were negative by IFAT but positive by cELISA (Table 2).

The concordance between the two serological methods for T. equi using the $\kappa$ coefficient was 0.68 . According to Landis and Koch's rating scale for the $\kappa$ index, there was substantial agreement between the techniques. A fair agreement (Cohen's $\kappa=0.22$ ) was observed between the techniques for $B$. caballi.

\section{Discussion}

Equine piroplasmoses are diseases that affect a large number of horses worldwide. Spain is an enzootic zone; therefore, information about the prevalence of this infection in horse populations is essential to control the disease and to reduce the economic losses generated. Different serological tests are available for epidemiological studies (IFAT, cELISA) [56, 58]. Currently, both techniques are recommended by the World 
Table 2. Serological results by IFAT and cELISA for T. equi (A) and B. caballi (B), respectively.

\begin{tabular}{llccc}
\hline & & \multicolumn{3}{c}{ cELISA } \\
\cline { 3 - 5 } & & Positive & Negative & Total \\
\hline T. equi (A) & & 48 & 7 & 55 \\
IFAT & Positive & 10 & 43 & 53 \\
& Negative & 58 & 50 & 108 \\
B. caballi (B) & Total & & & \\
IFAT & Positive & 4 & 16 & 20 \\
& Negative & 3 & 85 & 88 \\
& Total & 7 & 101 & 108 \\
\hline
\end{tabular}

Organisation for Animal Health for importation [73]. This study mainly used the IFAT and 108 randomly selected samples were analysed using both methods. Importantly, survey samples were collected from a large area in Spain, which made it possible to estimate the overall prevalence in a more realistic manner. Several studies on the seroprevalence of EPs in Spain have been published, although most of them were not as extensive as the present survey. These diseases are widespread in Spain and seroprevalence is high, as it has been reported by other authors $[21,22,35,41,43]$.

Recently, a survey carried out in all of Spain showed a T. equi seroprevalence of $21.9 \%$, a prevalence of $5 \%$ for B. caballi and co-infection in $2.71 \%$ of the tested animals using the cELISA [22]. In the Andalusia region, García-Bocanegra et al. [35] reported a slightly higher seroprevalence for $T$. equi (48.6\% vs. $43.61 \%$ in the present survey), but the B. caballi prevalence was $7.9 \%$ in the former, while in the present study it was $22.22 \%$. In 2005, Camacho et al. [21] in Galicia (northwest Spain) estimated the seropositivity for B. caballi to be $28.3 \%$ in healthy horses using IFAT, which was similar to our results. The difference could be explained by variations in abiotic factors and tick fauna distribution. Furthermore, the particular results for $B$. caballi may also be explained by the use of different diagnostic techniques. Thus, in the present study, it was revealed that the agreement between the cELISA and the IFAT was poorer for B. caballi. This difference could be due to the fact that IFAT slides were made with an autochthonous strain, while the commercial cELISA kit used a $R A P-1$ foreign antigen, leading to differences in the specificity and the sensitivity of the techniques. As we did, Camacho et al. [21] used the same IFAT technique, which led to a more accurate comparison among regions using the data from both studies. The prevalence estimated in other countries with IFAT or cELISA was different from the present survey. The EP prevalence was higher than in Spain in countries such as Colombia ( $\geq 90 \%$ ) [98], Brazil $78.8 \%$ and $65.7 \%$ for $T$. equi and B. caballi, respectively, [44] or $97.5 \%$ for EP [100] and Mongolia with $82.3 \%$ EP seroprevalence [16], or $78.8 \%$ for T. equi and $65.7 \%$ for B. caballi, respectively [84]. However, it was lower in countries such as the UAE (33.3\%) [48], Sudan (25.2\%) [85], Portugal (17.9\% and $11.1 \%$ for $T$. equi and B. caballi, respectively) [80], Turkey (18.4-18.5\%) [51, 90], Jordan (14.6\%) [2], Greece (11.6\%) [56], Saudi Arabia (10.4\% and $7.5 \%$ for $T$. equi and B. caballi, respectively) [6], Italy (8.5\%) [40], Switzerland (7.3\%) [92], the Netherlands
(4\%) [19] and Korea (1.1\%) [87]. In other studies, the T. equi seroprevalence was higher than that described in Spain, but the seropositivity for $B$. caballi was lower, this is the case for France (from $58 \%$ to $80 \%$ for $T$. equi and from $1.2 \%$ to $12.9 \%$ for B. caballi) [33, 38] and Iran (48\% and $2 \%)$ [1]. Meanwhile, a lower prevalence of $T$. equi was described in Hungary (32\%) [30], northern Italy (12.4\%) [67] and the Azores Islands (9.1\%) [11]. The EP seroprevalence discrepancies could be related to housing conditions, grazing and activity of horses $[38,56,100]$. Also, the measures for control of these diseases, the selected test for the diagnosis [2, 35, 56, 67], the climate and the tick fauna could be important. Thus, temperature and/or humidity and/or precipitation could increase or decrease tick populations [56, 94-96].

Using the IFAT, the T. equi seroprevalence was higher than that of $B$. caballi. Different trends were observed by other authors using different techniques (Table 3). T. equi was the predominant parasite in $82.14 \%$ of the studies in respect to $B$. caballi, but after excluding two studies $[60,81]$ due to discrepancies between diagnostic methods regarding the predominant haemoparasite.

Infected horses may remain lifelong carriers of T. equi, whereas $B$. caballi is eliminated from the bloodstream 1-4 years post-infection, which could explain the seroprevalence difference for these parasites [12, 28, 85]. This fact could explain why in horses older than nine years, the percentage of infected animals exceeds that of uninfected animals in the case of T. equi, which never occurs for B. caballi. Furthermore, treatments do not completely eliminate $T$. equi from the animals $[18,28]$. The situation reported by other authors is different since $B$. caballi is more prevalent than $T$. equi, which has been related to the presence of the appropriate tick vectors for the transmission of $B$. caballi [69].

Several authors $[4,12,35,38,45,49,50,56,70,74,77$, $79,84,90,100]$ suggested that age was a risk factor, since older animals could have been exposed to ticks for a longer period than young animals. Nevertheless, other authors showed the absence of an age-prevalence relationship [1, 3, 8, 10, 17, $23,26,36,40,46,69,75,76,80,92,94]$. The present study pointed out that less than $1 / 4$ of the foals and yearlings were seropositive for both parasites, with an increase in the percentage of infected horses until stabilisation at 11 and 14 years of age for T. equi and B. caballi, respectively, as Cantú-Martínez et al. reported [23]. Other studies have also reported that T. equi antibodies were higher in older than in young animals $[8,9,27,50,51,56]$. In addition, Vieira et al. [100] indicate that the seroprevalence of $T$. equi increased with age but in contrast, the presence of antibodies to $B$. caballi decreased in the oldest animals, which resembles the pattern described in this study. There is evidence that animals infected with T. equi may become lifelong carriers [18]. However, infection with $B$. caballi may also persist in the subclinical state for 1-4 years only. This fact may partially explain our results, whereby $T$. equi seroprevalence remained over $60 \%$ from eleven years of age, but $B$. caballi seroprevalence did not exceed the level of $44 \%$ in 16-year-old horses in Spain, where these parasites cohabit.

It was found that Spanish breeds have a lower infection prevalence than non-native breeds. Sevinc et al. [90] and 
Table 3. T. equi and B. caballi prevalence by different diagnostic methods, including geographical distribution and predominant parasite.

\begin{tabular}{|c|c|c|c|c|c|c|}
\hline $\begin{array}{l}\text { Diagnostic } \\
\text { method }\end{array}$ & Continent & Country & $\begin{array}{l}\text { Sample } \\
\text { size }\end{array}$ & $\begin{array}{c}\text { Prevalence in } \% \\
\text { (T. equi vs. } B \text {. caballi) }\end{array}$ & $\begin{array}{l}\text { Predominant } \\
\text { parasite }\end{array}$ & References \\
\hline \multirow[t]{2}{*}{$\overline{\mathrm{CFT}}$} & America & Brazil & 582 & 28.5 and 54.6 & B. caballi $>$ T. equi & Kerber et al. 2009 [53] \\
\hline & Europe & France & 443 & 58 and 12.9 & T. equi $>$ B. caballi & Guidi et al. 2015 [38] \\
\hline \multirow[t]{27}{*}{ ELISA } & Africa & Egypt & 88 & 14.8 and 0 & T. equi $>$ B. caballi & Mahmoud et al. 2016 [62] \\
\hline & & Sudan & 158 & 63.5 and 4.4 & T. equi $>$ B. caballi & Salim et al. 2008 [85] \\
\hline & America & Brazil & 47 & 81 and 90 & B. caballi $>$ T. equi & Xuan et al. 2001 [104] \\
\hline & & Brazil & 582 & 26.6 and 69.6 & B. caballi $>$ T. equi & Kerber et al. 2009 [53] \\
\hline & & Brazil & 198 & 78.3 and 69.2 & T. equi $>$ B. caballi & Vieira et al. $2013[100]$ \\
\hline & & Costa Rica & 130 & 88.5 and 69.2 & T. equi $>$ B. caballi & Posada-Guzmán et al. 2015 [75] \\
\hline & & Venezuela & 360 & 50.3 and 70.5 & B. caballi $>$ T. equi & Mujica et al. 2011 [69] \\
\hline & & Venezuela & 694 & 14 and 23.2 & B. caballi $>$ T. equi & Rosales et al. 2013 [81] \\
\hline & Asia & China & 70 & 40 and 24.3 & T. equi $>$ B. caballi & Xuan et al. 2002 [105] \\
\hline & & China & 111 & 34 and 32 & T. equi $>$ B. caballi & $\mathrm{Xu}$ et al. 2003 [103] \\
\hline & & China & 1990 & 11.51 and 51.16 & B. caballi $>$ T. equi & Wang et al. 2014 [101] \\
\hline & & UAE & 105 & 32.4 and 4.8 & T. equi $>$ B. caballi & Jaffer et al. 2010 [48] \\
\hline & & India & 180 & 75 and 1.11 & T. equi $>$ B. caballi & Sumbria et al. 2016 [96] \\
\hline & & Japan & 2019 & 2.2 and 5.4 & B. caballi $>$ T. equi & Ikadai et al. 2002 [47] \\
\hline & & Jordan & 253 & 14.6 and 0 & T. equi $>$ B. caballi & Abutarbush et al. 2012 [2] \\
\hline & & Korea & 184 & 1.1 and 0 & T. equi $>$ B. caballi & Seo et al. 2011 [87] \\
\hline & & Mongolia & 254 & 72.8 and 40.1 & T. equi $>$ B. caballi & Boldbaatar et al. 2005 [16] \\
\hline & & Mongolia & 250 & 51.6 and 19.6 & B. caballi $>$ T. equi & Munkhjargal et al. 2013 [70] \\
\hline & & Pakistan & 430 & 41.2 and 21.6 & T. equi $>$ B. caballi & Hussain et al. 2014 [46] \\
\hline & & Thailand & 240 & 5.42 and 2.5 & T. equi $>$ B. caballi & Kamyingkird et al. 2014 [50] \\
\hline & & Turkey & 481 & 16.21 and 0.83 & T. equi $>$ B. caballi & Sevinc et al. 2008 [90] \\
\hline & & Turkey & 220 & 56.8 and 0 & T. equi $>$ B. caballi & Kurt and Yaman 2012 [57] \\
\hline & Europe & Greece & 524 & 9.2 and 1.1 & T. equi $>$ B. caballi & Kouam et al. $2010[56]$ \\
\hline & & Italy & 673 & 39.8 and 8.9 & T. equi $>$ B. caballi & Bartolomé del Pino et al. 2016 [12] \\
\hline & & Portugal & 162 & 17.9 and 11.1 & T. equi $>$ B. caballi & Ribeiro et al. 2013 [80] \\
\hline & & Spain & 380 & 48.6 and 7.9 & T. equi $>$ B. caballi & García-Bocanegra et al. 2013 [35] \\
\hline & & Spain & 1067 & 21.9 and 5 & T. equi $>$ B. caballi & Camino et al. 2016 [22] \\
\hline \multirow[t]{20}{*}{ IFAT } & Africa & Egypt & 88 & 23.9 and 17.0 & T. equi $>$ B. caballi & Mahmoud et al. 2016 [62] \\
\hline & & South Africa & 92 & 97.83 and 52.17 & T. equi $>$ B. caballi & Motloang et al. 2008 [68] \\
\hline & America & Brazil & 93 & 33.3 and 68.8 & B. caballi $>$ T. equi & Asgarali et al. 2007 [8] \\
\hline & & Brazil & 487 & 91.0 and 83 & T. equi $>$ B. caballi & Heim et al. 2007 [44] \\
\hline & & Mexico & 248 & 45.2 and 27.4 & T. equi $>$ B. caballi & Cantú-Martínez et al. 2012 [23] \\
\hline & Asia & Iran & 100 & 48 and 2 & T. equi $>$ B. caballi & Abedi et al. 2014 [1] \\
\hline & & Saudi Arabia & 241 & 10.4 and 7.5 & T. equi $>$ B. caballi & Alanazi et al. 2012 [6] \\
\hline & & Thailand & 240 & 8.75 and 5 & T. equi $>$ B. caballi & Kamyingkird et al. 2014 [50] \\
\hline & & Turkey & 110 & 64.5 and 4.5 & T. equi $>$ B. caballi & Akkan et al. 2003 [5] \\
\hline & & Turkey & 84 & 23.8 and 38 & B. caballi $>$ T. equi & Acici et al. 2008 [3] \\
\hline & & Turkey & 125 & 12.8 and 9.6 & T. equi $>$ B. caballi & Karatepe et al. 2009 [51] \\
\hline & & UAE & 105 & 33.3 and 10.5 & T. equi $>$ B. caballi & Jaffer et al. 2010 [48] \\
\hline & Europe & Italy & 412 & 12.4 and 17.9 & B. caballi $>$ T. equi & Moretti et al. 2010 [67] \\
\hline & & Italy & 294 & 8.2 and 0.3 & T. equi $>$ B. caballi & Grandi et al. 2011 [40] \\
\hline & & Italy & 300 & 41 and 26 & T. equi $>$ B. caballi & Laus et al. 2013 [60] \\
\hline & & Italy & 1441 & 32.2 and 1.9 & T. equi $>$ B. caballi & Sgorbini et al. 2015 [89] \\
\hline & & Netherlands & 300 & 1 and 3 & B. caballi $>$ T. equi & Butler et al. 2012 [19] \\
\hline & & Spain & 60 & 40 and 28.3 & T. equi $>$ B. caballi & Camacho et al. 2005 [21] \\
\hline & & Spain & - & 52.5 and 21.3 & T. equi $>$ B. caballi & Habela et al. 2005 [43] \\
\hline & & Switzerland & 689 & 4.4 and 1.5 & T. equi $>$ B. caballi & Sigg et al. $2010[92]$ \\
\hline \multirow[t]{10}{*}{ PCR } & Africa & Egypt & 88 & 36.4 and 19.3 & T. equi $>$ B. caballi & Mahmoud et al. 2016 [62] \\
\hline & & South Africa & 92 & 5.43 and 0 & T. equi $>$ B. caballi & Motloang et al. 2008 [68] \\
\hline & & Sudan & 131 & 25.2 and 0 & T. equi $>$ B. caballi & Salim et al. 2008 [85] \\
\hline & & Sudan & 499 & 35.95 and 0 & T. equi $>$ B. caballi & Salim et al. 2013 [86] \\
\hline & & Tunisia & 104 & 11.54 and 0.96 & T. equi $>$ B. caballi & Ros-García et al. 2013 [82] \\
\hline & America & Brazil & 487 & 59.7 and 12.5 & T. equi $>$ B. caballi & Heim et al. 2007 [44] \\
\hline & & Costa Rica & 130 & 46.2 and 20 & T. equi $>$ B. caballi & Posada-Guzmán et al. 2015 [75] \\
\hline & & Guatemala & 74 & 52 and 48 & T. equi $>$ B. caballi & Teglas et al. 2005 [97] \\
\hline & & Venezuela & 136 & 61.8 and 4.4 & T. equi $>$ B. caballi & Rosales et al. 2013 [81] \\
\hline & Asia & India & 180 & 14.14 and 0 & T. equi $>$ B. caballi & Sumbria et al. 2016 [96] \\
\hline
\end{tabular}


Table 3. (continued)

\begin{tabular}{|c|c|c|c|c|c|c|}
\hline $\begin{array}{l}\text { Diagnostic } \\
\text { method }\end{array}$ & Continent & Country & $\begin{array}{l}\text { Sample } \\
\text { size }\end{array}$ & $\begin{array}{c}\text { Prevalence in } \% \\
\text { (T. equi vs. } B . \text { caballi) }\end{array}$ & $\begin{array}{l}\text { Predominant } \\
\text { parasite }\end{array}$ & References \\
\hline & \multirow{15}{*}{ Europe } & Iran & 100 & 45 and 0 & T. equi $>$ B. caballi & Abedi et al. $2014[1]$ \\
\hline & & Iran & 240 & 10.83 and 5.83 & T. equi $>$ B. caballi & Malekifard et al. 2014 [63] \\
\hline & & Jordan & 288 & 18.8 and 7.3 & T. equi $>$ B. caballi & Qablan et al. 2013 [77] \\
\hline & & Korea & 224 & 0.9 and 0 & T. equi $>$ B. caballi & Seo et al. 2013 [88] \\
\hline & & Turkey & 200 & 7 and 3 & T. equi $>$ B. caballi & Güçlü and Karaer 2007 [37] \\
\hline & & Turkey & 203 & 2.96 and 1.97 & T. equi $>$ B. caballi & Kizilarslan et al. 2015 [55] \\
\hline & & Turkey & 125 & 8.8 and 0 & T. equi $>$ B. caballi & Guven et al. 2017 [39] \\
\hline & & Mongolia & 192 & 92.7 and 1.2 & T. equi $>$ B. caballi & Sloboda et al. 2011 [93] \\
\hline & & Mongolia & 250 & 6.4 and 42.4 & B. caballi $>$ T. equi & Mans et al. 2015 [64] \\
\hline & & $\begin{array}{l}\text { Central } \\
\text { Balkans }\end{array}$ & 142 & 22.5 and 2.1 & T. equi $>$ B. caballi & Davitkov et al. 2016 [26] \\
\hline & & France & 111 & 80 and 1.2 & T. equi $>$ B. caballi & Fritz $2010[33]$ \\
\hline & & Italy & 294 & 2.72 and 0 & T. equi $>$ B. caballi & Grandi et al. 2011 [40] \\
\hline & & Italy & 300 & 6.0 and 11.7 & B. caballi $>$ T. equi & Laus et al. $2013[60]$ \\
\hline & & Italy & 263 & 70.3 and 10.3 & T. equi $>$ B. caballi & Bartolomé del Pino et al. 2016 [12] \\
\hline & & Romania & 178 & 20.3 and 2.2 & T. equi $>$ B. caballi & Gallusová et al. 2014 [34] \\
\hline
\end{tabular}

Aharonson-Raz et al. [4] recognised that the seroprevalence in Arabian horses was higher, as also found in the present study, especially for $B$. caballi. Bartolomé del Pino et al. [12] indicated that the prevalence in crossbred horses was significantly higher than other (pure) breeds. Other surveys showed no association between infection prevalence and breed [2, 10, 36, 75].

Shkap et al. [91] considered that the differences in prevalence between male and female horses may be due to different management practices for the two sexes. In the present study, however, differences between male and female horses were not observed.

In contrast to Aharonson-Raz et al. [4], no significant association between coat colour and the results of the diagnostic test was observed. Further studies are needed to understand the origin of this difference.

Significantly higher seroprevalence was obtained only in Extremadura and Castilla-León horses. There have also been studies that demonstrated statistically significant differences between counties or regions $[2,3,8,12,16,26,29,35,51$, 52, 56, 87, 91, 94, 96].

With respect to Cohen's $\kappa$ analysis, the concordance between the IFAT and the cELISA for T. equi was higher than for $B$. caballi, showing a fair agreement for $B$. caballi. The EMA-1 gene of the strains used to make the T. equi recombinant antigen in the cELISA and the strains from Spain were probably similar. Consequently, for $B$. caballi, the different results between this technique and cELISA may be related to this fact. However, the $R A P-1$ gene of strains used to make the recombinant antigen in the cELISA could be different from the RAP-1 gene of Spanish strains. Recently, Montes et al. [66] showed one Spanish $B$. caballi strain to be genetically different from that described by Cacciò et al. [20] based on the $\beta$-tubulin gene. Also, the existence of genetic differences between strains within a country or among countries has been reported previously $[14,25,71]$. These authors showed that there was heterogeneity in the $18 S$ rRNA gene both for T. equi and B. caballi in Spain and South Africa. In support of our study and focusing on the $R A P-1$ gene of $B$. caballi, Bhoora et al. [15], Rapoport et al. [79] and Mahmoud et al. [62] indicated failure to detect the $B$. caballi parasite. In accordance with Rapoport et al. [79], there could be doubts as to the ability of the cELISA to serve as a sole regulatory test for the international horse trade. The IFAT used in the present survey was performed with Spanish B. caballi strains, since it appears that they detect the presence of haemoparasite antibodies more successfully than the cELISA. Thus, Kuttler et al. [59] and Prochno et al. [76] confirmed that, due to regional differences, the use of antigens from autochthonous strains provides the best results.

\section{Conclusions}

The risk factors that seem to be associated with the presence of equine piroplasmoses in Spain are age, breed and geographical location. Meanwhile, coat colour and gender were not significantly associated in these diseases. The seroprevalence in young animals is relatively low, but as horses get older they become seropositive, especially concerning T. equi. In addition, the comparison between IFAT and cELISA revealed a possible underestimation of the presence of B. caballi when using cELISA.

\section{Conflict of interest}

The authors declare there is no conflict of interest

Acknowledgements. The authors would like to thank the field veterinarians and the owners of the horses. They also thank Dr. Jacinto Garrido Velarde for his help with map design. Also we thank the "Junta de Extremadura, Consejería de Economía e Infraestructuras - Ayuda GR15085-; and Fondo Europeo de Desarrollo Regional (FEDER)/European Regional Development Fund (ERDF)".

\section{References}

1. Abedi V, Razmi G, Seifi H, Naghibi A. 2014. Molecular and serological detection of Theileria equi and Babesia caballi infection in horses and ixodid ticks in Iran. Ticks and Tickborne Diseases, 5(3), 239-244. 
2. Abutarbush SM, Alqawasmeh DM, Mukbel RM, Al-Majali AM. 2012. Equine babesiosis: Seroprevalence, risk factors and comparison of different diagnostic methods in Jordan. Transboundary and Emerging Diseases, 59(1), 72-78.

3. Acici M, Umur S, Givenc T, Arslan HH, Kurt M. 2008. Seroprevalence of equine babesiosis in the Black Sea region of Turkey. Parasitology International, 57(2), 198-200.

4. Aharonson-Raz K, Rapoport A, Hawari IM, Lensky IM, Berlin D, Zivotofsky D, Klement E, Steinman A. 2014. Novel description of force of infection and risk factors associated with Theileria equi in horses in Israel and in The Palestinian Authority. Ticks and Tick-borne Diseases, 5(4), 366-372.

5. Akkan HA, Karaca M, Tutuncu M, Deger S, Keles I, Agaoglu Z. 2003. Serologic and microscopic studies on babesiosis in horses in the eastern border of Turkey. Journal of Equine Veterinary Sciences, 5(23), 181-183.

6. Alanazi AD, Alyousif MS, Hassieb MM. 2012. Seroprevalence study on Theileria equi and Babesia caballi antibodies in horses from central province of Saudi Arabia. Journal of Parasitology, 98(5), 1015-1017.

7. Alhassan A, Pumidonming W, Okamura M, Hirata H, Battsetseg B, Fujisaki K, Yokoyama N, Igarashi I. 2005. Development of a single-round and multiplex PCR method for the simultaneous detection of Babesia caballi and Babesia equi in horse blood. Veterinary Parasitology, 129(1-2), 43-49.

8. Asgarali Z, Coombs DK, Mohammed F, Campbell MD, Caesar E. 2007. A serological study of Babesia caballi and Theileria equi in thoroughbreds in Trinidad. Veterinary Parasitology, 144(1-2), 167-171.

9. Ayala-Valdovinos MA, Lemus-Flores C, Galindo-García J, Bañuelos-Pineda J, Rodríguez-Carpena JG, Sánchez-Chiprés D, Duifhuis-Rivera T. 2017. Diagnosis and prevalence of Theileria equi in western Mexico by nested PCR. Parasitology International, 66, 821-824.

10. Bahrami S, Ghadrdan AR, Mirabdollahi SM, Fayed MR. 2014. Diagnosis of subclinical equine theileriosis in center of Iran using parasitological and molecular methods. Tropical Biomedicine, 31(1), 110-117.

11. Baptista C, Lopes MS, Tavares AC, Rojer H, Kappmeyer L, Mendoça D, da Câmara Machado A. 2013. Diagnosis of Theileria equi infections in horses in the Azores using cELISA and nested PCR. Ticks and Tick-borne Diseases, 4(3), 242-245.

12. Bartolomé del Pino LE, Nardini R, Veneziano V, Iacoponi F, Cersini A, Autorino GL, Buono F, Sicluna MT. 2016. Babesia caballi and Theileria equi infections in horses in CentralSouthern Italy: Sero-molecular Surrey and associated risk factors. Ticks and Tick-borne Diseases, 7, 462-469.

13. Bashiruddin JB, Cammà C, Rebelo E. 1999. Molecular detection of Babesia equi and Babesia caballi in horse blood by PCR amplification of part of the 16S rRNA gene. Veterinary Parasitology, 84, 75-83.

14. Bhoora R, Franssen L, Oosthuizen MC, Guthrie AJ, Zweygarth E, Penzhorn BL, Jongejan F, Collins NE. 2009. Sequence Heterogeneity in the 18S rRNA gene within Theileria equi and Babesia caballi from horses in South Africa. Veterinary Parasitology, 159, 112-120.

15. Bhoora R, Quan M, Zweygarth E, Guthrie AJ, Prinsloo SA, Collins NE. 2010. Sequence heterogeneity in the gene encoding the rhoptry-associated protein-1 (RAP-1) of Babesia caballi isolates from South Africa. Veterinary Parasitology, 169(3-4), 279-288.

16. Boldbaatar D, Xuan X, Battsetseg B, Igarashi I, Battur B, Batsukh Z, Bayambaa B, Fujisaki K. 2005. Epidemiological study of equine piroplasmosis in Mongolia. Veterinary Parasitology, 127(1), 29-32.

17. Botteon PTL, Massard CL, Botteon RCCM, Loss ZG, Linhares GFC. 2002. Seroprevalence of Babesia equi in three breeding systems of equines. Rio de Janeiro-Brazil. Parasitología Latinoamericana, 57(3-4), 141-145.

18. Brüning A. 1996. Equine piroplasmosis: an update on diagnosis, treatment and prevention. British Veterinary Journal, 152(2), 139-151.

19. Butler CM, Sloet van Oldruitenborgh-Oosterbaan MM, Stout TAE, van der Kolk JH, Lv Wollenberg, Nielen M, Jongejan F, Werners AH, Houwers DJ. 2012. Prevalence of the causative agents of equine piroplasmosis in the South West of The Netherlands and the identification of two autochthonous clinical Theileria equi infections. The Veterinary Journal, 193(2), 381-385.

20. Cacciò $\mathrm{S}$, Cammà C, Onuma $\mathrm{M}$, Severini C. 2000. The betatubulin gene of Babesia and Theileria parasites is an informative marker for species discrimination. International Journal for Parasitology, 30, 1181-1185.

21. Camacho AT, Guitian FJ, Pallas E, Gestal JJ, Olmeda AS, Habela MA, Telford SR III, Spielman A. 2005. Theileria (Babesia) equi and Babesia caballi infections in horses in Galicia, Spain. Tropical Animal Health and Production, 37(4), 293-302.

22. Camino E, Carvajal KA, Lozano FJ, Viñolo C, Alende T, Domínguez L, Cruz F. 2016. Estudio de seroprevalencia de piroplamosis equina en España en muestras previas a la exportación. XXI Simposio Anual Avedila, Murcia.

23. Cantú-Martínez MA, Segura-Correa JC, Silva-Páez ML, Avalos-Ramírez R, Wagner GG. 2012. Prevalence of antibodies to Theileria equi and Babesia caballi in horses from Northeastern Mexico. Journal of Parasitology, 98(4), 869-870.

24. Cohen J. 1960. A coefficient of agreement for nominal scales. Educational and Psychological Measurement, 20, 37-46.

25. Criado-Fornelio A, González-del-Río MA, Buling-Saraña A, Barba-Carretero JC. 2004. The "expanding universe" of piroplasms. Veterinary Parasitology, 119(4), 337-345.

26. Davitkov D, Vucicevic M, Stevanovic J, Krstic V, Slijepcevic D, Glavinic U, Stanimirovic Z. 2016. Molecular detection and prevalence of Theileria equi and Babesia caballi in horses of central Balkan. Acta Parasitologica, 61(2), 337-342.

27. De Campos CHC, Prado RFS, Guimãraes A, da Silva AT, Baldani CD, Cordeiro MD, Pires MS, Peixoto MP, dos Santos HA, Machado RZ, Fonseca AH, Massard CL. 2013. Aspectos epidemiológicos e soroprevalência de Theileria equi em equinos de uso military no munícipio de Resende, estado do Rio de Janeiro, Brasil. Revista Brasileira de Medicina Veterinária, 35(S2), 106-112.

28. De Waal DT, Van Heerden J. 1994. Equine Piroplasmosis, in Infectious Diseases of Livestock, Coetzer JAW, Tustin RC, Editors. Oxford University Press: New York. p. 295-304.

29. Dos Santos TM, Roier EC, dos Santos HA, Pires MS, Vilela JA, Moraes LM, Almeida FQ, Baldani CD, Machado RZ, Massard CL. 2011. Factors associated to Theileria equi in equids of two microregions from Rio de Janeiro. Brazil. Revista Brasileira de Parasitologia Veterinária, 20(3), 235-241.

30. Farkas R, Tanczos B, Gyurkovszky M, Fölsvári G, Solymosi N, Edelhofer R, Hornok S. 2013. Serological and molecular detection of Theileria equi infection in horses in Hungary. Veterinary Parasitology, 192, 143-148. 
31. Friedhoff KT, Tenter AM, Müller I. 1990. Haemoparasites of equines: impact on international trade of horses. Revue Scientifique et Technique Office International des Épizooties, 9(4), 1187-1194.

32. Friedhoff KT, Soulé C. 1996. An account on equine babesiosis. Revue Scientifique et Technique Office International des Épizooties, 15, 1191-1201.

33. Fritz D. 2010. A PCR study of piroplasms in 166 dogs and 111 horses in France (March 2006 to March 2008). Parasitology Research, 106(6), 1339-1342.

34. Gallusová M, Qablan MA, D’Amico G, Oborník M, Petrželková KJ, Mihalca AD, Modrý D. 2014. Piroplasms in feral and domestic equines in rural areas of the Danube Delta, Romania, with survey of dogs as a possible reservoir. Veterinary Parasitology, 206(3-4), 287-292.

35. García-Bocanegra I, Arenas-Montes A, Hernández E, Adaszek L, Carbonero A, Almería S, Jaén-Téllez JA, Gutiérrez-Palomino P, Arenas A. 2013. Seroprevalence and risk factors associated with Babesia caballi and Theileria equi infection in equids. Veterinary Journal, 195(2), 172-178.

36. Golynski AA, Fernandes KR, Baldani CD, Golynski AL, Madeiro AS, Machado RZ, Botteon P de T, Massard CL. 2008. Seroepidemiological studies on Babesia equi in horses from the State of Rio Grande do Sul determined by indirect immunofluorescence test and Elisa. Revista Brasileira de Parasitologia Veterinária, 17(S1), 317-321.

37. Güçlü HZ, Karaer KZ. 2007. Detection of Babesia caballi (Nuttall, 1910) and Theileria equi (Syn. Babesia equi, Laveran, 1901) by the polymerase chain reaction (PCR) in show and sport horses in the region of Ankara. Turkiye Parazitologi Dergisi, 31(2), 89-93.

38. Guidi E, Pradier S, Lebert I, Leblond A. 2015. Piroplasmosis in an endemic area: analysis of the risk factors and their implications in the control of theileriosis and babesiosis in horses. Parasitology Research, 114(1), 71-83.

39. Guven E, Avcioglu H, Deniz A, Balkaya İ, Abay U, Yavuz Ş, Akyüz M. 2017. Prevalence and molecular characterization of Theileria equi and Babesia caballi in jereed horses in Erzurum, Turkey. Acta Parasitologica, 62(1), 207-213.

40. Grandi G, Molinari G, Tittarelli M, Sassera D, Kramer LH. 2011. Prevalence of Theileria equi and Babesia caballi infection in horses from Northern Italy. Vector-Borne and Zoonotic Diseases, 11(7), 955-956.

41. Habela M, Reina D, Nieto D, Verdugo SG, Navarrete I. 1989. Epidemiología de la babesiosis equina en Extremadura: estudio preliminar. Medicina Veterinaria, 6, 31-39.

42. Habela M, Grande A, Antón JM, Mora JA, Moreno F, Pérez-Martín JE. 1995. Aportaciones al conocimiento de la distribución y clínica de la babesiosis equina en España. IV Congreso Ibérico de Parasitología, Santiago de Compostela.

43. Habela MA, Gragera-Slikker A, Moreno A, Montes G, Sevilla R. 2005. Piroplasmosis equina: conocimiento y grado de concienciación de los productores de caballos Pura Raza Española. Revista Equinus, 11, 17-34.

44. Heim A, Passos LM, Ribeiro MF, Costa-Júnior LM, Bastos CV, Cabral DD, Hirzmann J, Pfister K. 2007. Detection and molecular characterizaion of Babesia caballi and Theileria equi isolates from endemic areas of Brazil. Parasitology Research, 102(1), 63-68.

45. Heuchert CM, de Giulli V, de Athaide DF, Böse R, Friedhoff KT. 1999. Seroepidemiologic studies on Babesia caballi infections in Brazil. Veterinary Parasitology, 85, 1-11.
46. Hussain MH, Saqib M, Raza F, Muhammad G, Asi MN, Mansoor MK, Saleem M, Jabbar A. 2014. Seroprevalence of Babesia caballi and Theileria equi in five draught equine populated metropolises of Punjab, Pakistan. Veterinary Parasitology, 202(3-4), 248-256.

47. Ikadai H, Nagai A, Xuan X, Igarashi I, Kamio T, Tsuji N, Oyamada T, Suzuki N, Fujisaki K. 2002. Seroepidemiologic studies on Babesia caballi and Babesia equi infections in Japan. Journal of Veterinary Medicine Science, 64(4), 325-328.

48. Jaffer O, Abdishakur F, Hakimuddin F, Riya A, Wernery U, Schuster RK. 2010. A comparative study of serological tests and PCR for the diagnosis of equine piroplasmosis. Parasitology Research, 106(3), 709-713.

49. Javed K, Ijaz M, Ali MM, Khan I, Mehmood K, Ali S. 2014. Prevalence and hematology of tick borne hemoparasitic diseases in Equines in and around Lahore, Pakistan. Journal of Zoology, 46(2), 401-408.

50. Kamyingkird K, Yangtara S, Desquesnes M, Cao S, Adjou PK, Jittapalapong S, Nimsupan B, Terkawi MA, Masatani T, Nishikawa Y, Igarashi I, Xuan X. 2014. Seroprevalence of Babesia caballi and Theileria equi in horses and mules from Northern Thailand. Journal of Protozoology Research, 24, $11-17$.

51. Karatepe B, Karatepe M, Cakmak A, Karaer Z, Ergün G. 2009. Investigation of seroprevalence of Theileria equi and Babesia caballi in horses in Nidge province, Turkey. Tropical Animal Health and Production, 41(1), 109-113.

52. Kerber CE, Ferreira F, Pereira MC. 1999. Control of equine piroplasmosis in Brazil. Onderstepoort Journal of Veterinary Research, 66, 123-127.

53. Kerber CE, Labruna MB, Ferreira F, De Waal DT, Knowles DP, Gennari SM. 2009. Prevalence of equine Piroplasmosis and its association with tick infestation in the State of São Paulo, Brazil. Revista Brasileira de Parasitologia Veterinária, 18(4), $1-8$.

54. Kim C, Conza LB, Alhassan A, Iseki H, Yokoyama N, Xuan X, Igarashi I. 2008. Diagnostic real-time PCR assay for the quantitative detection of Theileria equi from equine blood samples. Veterinary Parasitology, 151, 158-163.

55. Kizilarslan F, Yildirim A, Duzlu O, Inci A, Onder Z, Ciloglu A. 2015. Molecular detection and characterization of Theileria equi and Babesia caballi in horses (Equus ferus caballus) in Turkey. Journal of Equine Veterinary Science, 35, 830-835.

56. Kouam MK, Kantzoura V, Gajadhar AA, Theis JH, Papadopoulos E, Theodoropoulos G. 2010. Seroprevalence of equine piroplasms and host-related factors associated with infection in Greece. Veterinary Parasitology, 169(3-4), 273-278.

57. Kurt C, Yaman M. 2012. The investigation of the prevalence of Babesia equi and Babesia caballi in horses by microscopic and serologic (cELISA) methods in Adana Province. Yüzüncü yil Úniversitesi Veterinary Fakültesi Dergisi, 23(1), 1-4.

58. Kuttler KL. 1988. World-Wide impact of babesiosis, in Babesiosis of domestic animals and man. Ristic M, Editor. CRC Press: Boca Ratón, Florida. p. 1-22.

59. Kuttler KL, Goff WL, Gipson CA, Blackburn BO. 1988. Serologic response of Babesia equi infected horses as measured by complement-fixation and indirect fluorescent antibody tests. Veterinary Parasitology, 26(3-4), 199-205.

60. Laus F, Veronesi F, Passamonti F, Paggi E, Cerquetella M, Hyatt D, Tesei B, Fioretti DP. 2013. Prevalence of tick borne pathogens in horses from Italy. Journal of Veterinary Medicine Science, 75(6), 715-720. 
61. MAGRAMA. 2013. http://www.mapama.gob.es/es/ ganaderia/temas/produccion-y-mercados-ganaderos/ indicadoreseconomicossectorequino2015_tcm7-386080.pdf (accessed 27 February 2017).

62. Mahmoud MS, El-Ezz NT, Abdel-Shafy S, Nassar SA, El Namaky AH, Khalil WK, Knowles D, Kappmeyer L, Silva MG, Suarez CE. 2016. Assessment of Theileria equi and Babesia caballi infections in equine populations in Egypt by molecular, serological and haematological approaches. Parasites and Vectors, 9(1), 260.

63. Malekifard F, Tavassoli M, Yakhchali M, Darvishzadeh R. 2014. Detection of Theileria equi and Babesia caballi using microscopic and molecular methods in horses in suburb of Urmia, Iran. Veterinary Research Forum, 5(2), 129-133.

64. Mans BJ, Pienaar R, Latif AA. 2015. A review of Theileria diagnostics and epidemiology. International Journal for Parasitology, 4, 104-118.

65. Mehlhorn H, Schein E. 1998. Redescription of Babesia equi (Laveran, 1901) as Theileria equi (Mehlhorn, Schein 1998). Parasitology Research, 84, 467-475.

66. Montes MG, Fernández-García JL, Habela MA. in press. Genetic variation of the beta-tubulin gene of Babesia caballi strains. Journal of Arthropod-Borne Diseases.

67. Moretti A, Mangili V, Salvatori R, Maresca C, Scoccia E, Torina A, Moretta I, Gabrielli S, Tampieri MP, Pietrobelli M. 2010. Prevalence and diagnosis of Babesia and Theileria infections in horses in Italy: a preliminary study. Veterinary Journal, 184(3), 346-350.

68. Motloang MY, Thekisoe OMM, Alhassan A, Bakheit M, Motheo MP, Masangane FES, Thibedi ML, Inoue N, Igarashi I, Sugimoto C, Mbati PA. 2008. Prevalence of Theileria equi and Babesia caballi infections in horses belonging to resource-poor farmers in the north-eastern Free State Province, South Africa. Onderstepoort Journal of Veterinary Research, 75, 141-146.

69. Mujica FF, Perrone T, Forlano M, Coronado A, Meléndez RD, Barrios N, Álvarez R, Granda F. 2011. Serological prevalence of Babesia caballi and Theileria equi in horses of Lara State, Venezuela. Veterinary Parasitology, 178(1-2), 180-183.

70. Munkhjargal T, Sivakumar T, Battsetseg B, Nyamjargal T, Aboulaila M, Purevtseren B, Bayarsaikhan D, Byambaa B, Terkawi MA, Yokoyama N, Igarashi I. 2013. Prevalence and genetic diversity of equine piroplasms in Tov province, Mongolia. Infection, Genetics and Evolution, 16, 178-185.

71. Nagore D, García-Sanmartín J, García-Pérez AL, Juste RA, Hurtado A. 2004. Detection and identification of equine Theileria and Babesia species by reverse line blotting: epidemiological Survey and phylogenetic analysis. Veterinary Parasitology, 123(1-2), 41-54.

72. Nicolaiewsky TB, Richter MF, Lunge VR, Cuhna CW, Delagostin O, Ikuta N, Fonseca AS, Silva SS, Ozaki LS. 2001. Detection of Babesia equi (Laveran, 1901) by nested polymerase chain reaction. Veterinary Parasitology, 101, 9-21.

73. OIE. 2017. Equine piroplasmosis, in Manual of diagnostic test and vaccines for terrestrial animals, http://www.oie.int/ fileadmin/Home/eng/Health_standards/tahc/current/chapitre_ equine_piroplasmosis.pdf (accessed 20 February 2017) (Chapter 12.7).

74. Olivera M, García F. 2001. Equine babesiosis seroprevalence in thoroughbred racing horse farms from Aragua and Carabobo State, Venezuela. Revista de la Facultad de Ciencias Veterinarias de la Universidad Central de Venezuela, 42(1-2), 3-13.
75. Posada-Guzmán MF, Dolz G, Romero-Zúñiga JJ, JiménezRocha AE. 2015. Detection of Babesia caballi and Theileria equi in blood from equines from four indigenous communities in Costa Rica. Veterinary Medicine International, 2015, 236278.

76. Prochno HC, Scorsin LM, De Melo FR, Baldani CD, Falbo MK, de Aquino LC, Lemos KR. 2014. Seroprevalence rates of antibodies against Theileria equi in team roping horses from central-western region of Paraná. Revista Brasileira de Parasitologia Veterinária, 23(1), 85-89.

77. Qablan MA, Obroník M, Petrželková KJ, Sloboda M, Shudiefat MF, Hořín P, Lukeš J, Modrý D. 2013. Infections by Babesia caballi and Theileria equi in Jordanian equids: epidemiology and genetic diversity. Parasitology, 140(9), 1096-1103.

78. Rampersad J, Cesar E, Campbell MD, Samlal M, Ammons D. 2003. A field evaluation of PCR for the routine detection of Babesia equi in horses. Veterinary Parasitology, 114, 81-87.

79. Rapoport A, Aharonson-Raz K, Berlin D, Tal S, Gottlieb Y, Klement E, Steinman A. 2014. Molecular characterization of the Babesia caballi rap-1 gene and epidemiological survey in horses in Israel. Infection, Genetics and Evolution, 23, $115-120$

80. Ribeiro AJ, Cardoso L, Maia JM, Coutinho T, Cotovio M. 2013. Prevalence of Theileria equi, Babesia caballi and Anaplasma phagocytophilum in horses from the north of Portugal. Parasitology Research, 112(7), 2611-2617.

81. Rosales R, Rangel-Rivas A, Escalona A, Jordan LS, Gonzatti MI, Asom PM, Perrone T, Silva-Iturriza A, Mijares A. 2013. Detection of Theileria equi and Babesia caballi infections in Venezuelan horses using competitive-inhibition ELISA and PCR. Veterinary Parasitology, 196(1-2), 37-43.

82. Ros-García A, M'ghirbi Y, Hurtado A, Bouattour A. 2013. Prevalence and genetic diversity of piroplasms species in horses and ticks from Tunisia. Infection, Genetics and Evolution, 17, 33-37.

83. Rothschild CM, Knowles DP. 2007. Equine Piroplasmosis, in Equine Infectious Diseases. Sello DC, Long MT, Editors. Saunders Elsevier: St. Louis, MO. p. 465-473.

84. Rüegg SR, Torgerson P, Deplazes P, Mathis A. 2007. Agedependent dynamics of Theileria equi and Babesia caballi infections in Southwest Mongolia based on IFAT and/or PCR prevalence data from domestic horses and ticks. Parasitology, 134(Pt 7), 939-947.

85. Salim BOM, Hassan SM, Bakheit MA, Alhassan A, Igarashi I, Karanis P, AbdeIrahman MB. 2008. Diagnosis of Babesia caballi and Theileria equi infections in horses in Sudan using ELISA and PCR. Parasitology Research, 103(5), 1145-1150.

86. Salim B, Bakheit MA, Kamau J, Sugimoto C. 2013. Current status of equine piroplasms in the Sudan. Infection, Genetics and Evolution, 16, 191-199.

87. Seo MG, Yun SH, Choi SK, Cho GJ, Park YS, Kwon OD, Cho KH, Kim TH, Jeong KS, Park SJ, Kwon YS, Kwak D. 2011. Seroprevalence of equine piroplasms in the Republic of Korea. Veterinary Parasitology, 179(1-3), 224-226.

88. Seo MG, Yun SH, Choi SK, Cho GJ, Park YS, Cho KH, Kwon OD, Kwak D. 2013. Molecular and phylogenetic analysis of equine piroplasms in the Republic of Korea. Research in Veterinary Science, 94, 579-583.

89. Sgorbini M, Bonelli F, Nardoni S, Rocchigiani G, Corazza M, Mancianti F. 2015. Seroprevalence and molecular analysis of Babesia caballi and Theileria equi from Central Italy during a 10-year period. Journal of Equine Veterinary Science, 35, 865-868. 
90. Sevinc F, Maden M, Kumas C, Sevinc M, Ekici OD. 2008. A comparative study on the prevalence of Theileria equi and Babesia caballi infections in horse sub-populations in Turkey. Veterinary Parasitology, 156(3-4), 173-177.

91. Shkap V, Cohen I, Leibovitz B, Savitsky Pipano E, Avni G, Shofer S, Giger U, Kappmeyer L, Knowles D. 1998. Seroprevalence of Babesia equi among horses in Israel using competitive inhibition ELISA and IFA assays. Veterinary Parasitology, 76(4), 251-259.

92. Sigg L, Gerber V, Gottstein B, Doherr MG, Frey CF. 2010. Seroprevalence of Babesia caballi and Theileria equi in the Swiss horse population. Parasitology International, 59(3), 313-317.

93. Sloboda $M$, Jirků $M$, Lukešová $D$, Qablan $M$, Batsukh $Z$, Fiala I, Hořín P, Modrý M, Lukeš J. 2011. A survey for piroplasmids in horses and Bactrian camels in North-Eastern Mongolia. Veterinary Parasitology, 179(1-3), 246-249.

94. Steinman A, Zimmerman T, Klement E, Lensky IM, Berlin D, Gottlieb Y, Baneth G. 2012. Demographic and environmental risk factors for infection by Theileria equi in 590 horses in Israel. Veterinary Parasitology, 187(3-4), 558-562.

95. Sumbria D, Singla LD, Kumar S, Sharma A, Dahiya RK, Setia R. 2016a. Spatial distribution, risk factors and haematobiochemical alterations associated with Theileria equi infected equids of Punjab (India) diagnosed by indirect ELISA and nested PCR. Acta Tropica, 155, 104-112.

96. Sumbria D, Singla LD, Sharma A. 2016. Theileria equi and Babesia caballi infection in equids in Punjab, India: a serological and molecular survey. Tropical Animal Health and Production, 48(1), 45-52.

97. Teglas M, Matern E, Lein S, Foley P, Mahan SM, Foley J. 2005. Ticks and tick-borne disease in Guatemalan cattle and horses. Veterinary Parasitology, 131(1-2), 119-127.

98. Tenter AM, Otte MJ, Gonzalez CA, Abuabara Y. 1988. Prevalence of piroplasmosis in equines in the Colombian province of Cordoba. Tropical Animal Health and Production, 20(2), 93-98.

99. Thrusfield M, Ortega C, de Blas I, Noordhuizen JP, Frankena K. 2001. Win Episcope 2.0: improved epidemiological software for veterinary medicine. Veterinary Record, 148(18), 567-572.

100. Vieira TS, Vieira RF, Finger MA, Nascimiento DA, Sicupira PM, Dutra LH, Deconto I, Barros-Filho IR, Dornbusch PT, Biondo AW, Vidotto O. 2013. Seroepidemiological survey of Theileria equi and Babesia caballi in horses from a rural and from urban areas of Paraná State, southern Brazil. Ticks and Tick-Borne Diseases, 4(6), 537-541.

101. Wang M, Guo W, Igarashi I, Xuan X, Wang X, Xiang W, Jia H. 2014. Epidemiological investigation of Equine Piroplasmosis in China by Enzyme-Linked Immunosorbent Assays. Journal of Veterinary Medicine Science, 76(4), 549-552.

102. Wise LN, Kappmeyer LS, Mealey RH, Knowles DP. 2013. Review of equine piroplasmosis. Journal of Veterinary Internal Medicine, 27, 1334-1346.

103. Xu Y, Zhang S, Huang X, Bayin C, Xuan X, Igarashi I, Fujisaki K, Kabeya H, Maruyama S, Mikami T. 2003. Seroepidemiologic studies on Babesia equi and Babesia caballi infections in horses in Jilin province of China. Journal of Veterinary Medicine Science, 65(9), 1015-1017.

104. Xuan X, Nagai A, Battsetseg B, Fukumoto S, Makala LH, Inoue N, Igarashi I, Mikami T, Fujisaki K. 2001. Diagnosis of equine piroplasmosis in Brazil by serodiagnostic methods with recombinant antigens. Journal of Veterinary Medicine Science, 63(10), 1159-1160.

105. Xuan X, Chahan B, Huang X, Yokohama N, Makala LH, Igarashi I, Fujisaki K, Maruyama S, Sakai T, Mikami T. 2002. Diagnosis of equine piroplasmosis in Xinjiang province of China by the enzyme-linked immunosorbent assays using recombinant antigens. Veterinary Parasitology, 108(2), 179-182.

Cite this article as: Montes Cortés MG, Fernández-García JL \& Habela Martínez-Estéllez MÁ: Seroprevalence of Theileria equi and Babesia caballi in horses in Spain. Parasite, 2017, 24, 14.

Reviews, articles and short notes may be submitted. Fields include, but are not limited to: general, medical and veterinary parasitology; morphology, including ultrastructure; parasite systematics, including entomology, acarology, helminthology and protistology, and molecular analyses; molecular biology and biochemistry; immunology of parasitic diseases; host-parasite relationships; ecology and life history of parasites; epidemiology; therapeutics; new diagnostic tools.

All papers in Parasite are published in English. Manuscripts should have a broad interest and must not have been published or submitted elsewhere. No limit is imposed on the length of manuscripts.

Parasite (open-access) continues Parasite (print and online editions, 1994-2012) and Annales de Parasitologie Humaine et Comparée (1923-1993) and is the official journal of the Société Française de Parasitologie. 